\title{
MOTIF MEDIA PEMBELAJARAN BUKU TEKS BIOLOGI DAN HUBUNGANNYA DENGAN KETERAMPILAN SISWA
}

\section{LEARNING MEDIA MOTIVE OF TEXT BOOK AND ITS RELATIONSHIP WITH STUDENT SKILL}

\author{
FA.Suherman' ${ }^{1}$, R Rahmawati $^{2}$, Sukarelawati ${ }^{3 a}$ \\ ${ }^{1}$ Alumni Ps. Ilmu Komunikasi, Fakultas Ilmu Sosial dan Ilmu Politik, Universitas Djuanda Bogor, ${ }^{2}$ Dosen \\ Pembimbing I Program Studi Komunikasi, Fakultas Ilmu Sosial dan Ilmu Politik, ${ }^{3}$ Dosen Pembimbing II \\ Program Studi Komunikasi Universitas Djuanda Bogor, Jl. Tol Ciawi No.1 Kotak Pos 35 Bogor 16720 \\ a Korespondensi: Sukarelawati, Email: Sukarelawati3d@yahoo.co.id
}

(Diterima: 07-07-2015; Ditelaah: 20-07-2015; Disetujui: 18-08-2015)

\begin{abstract}
This study focused on the relationship among learning media motive with student skill at SMA Taruna Andigha dan SMA Amaliah Bogor.The study porposed to: (1) To determine the motive of a Biology text book at SMA Taruna Andigha and SMA Amaliah Bogor, (2) to determine the student skill at SMA Taruna Andigha andSMA Amaliah Bogor, (3) To determine the relationship among learning media motive and student skill at SMA Taruna Andigha andSMA Amaliah Bogor. Type of research is associative method with a quantitative approach. The result showed that (1) Power of Learning media motive in motivate student, student could learn wherever and whenever, interative class, and demonstrationwas unfavourable. (2) Student skill problem solving ability, Flexibility to analyze problem, matter elaboration, and making new creation for themselves or enviroment was good, (3)learning media motive had no corelation with student skill.
\end{abstract}

keywords: mass media communication, Learning media, student skill

\begin{abstract}
ABSTRAK
Penelitian ini memusatkan perhatian pada hubungan antara media pembelajaran dengan keterampilan siswa. Penelitian ini bertujuan: (1) mengetahui motif media pembelajaran di SMA Taruna Andigha dan SMA Amaliah Bogor, (2) mengetahui keterampilan siswa di SMA Taruna Andigha dan SMA Amaliah Bogor, (3) mengetahui hubungan antara motif media pembelajaran dengan keterampilan siswa di SMA Taruna Andigha dan SMA Amaliah Bogor. Jenis penelitian yang digunakan adaah metode asosiatif dengan pendekatan kuantitatif. Hasil penelitian menunjukan bahwa (1) kekuatan motif media pembelajaran adalah menimbulkan motivasi belajar siswa, metode mengajat bervariasi, interaktif siswa dan guru, dan adanya demonstrasi termasuk pada kategori kurang baik. (2) Keterampilan siswa dinilai berdasarkan beberapa kriteria seperti banyak gagasan, keluwesan danal memecahkan masalah, mencetuskan gagasan asli, menguraikan ssesuatu dengan rinci, menghasilkan karya yang bermanfaat bagi individu dan lingkungan dinilai baik, (3) kekuatan motif media pembelajaran dengan keterampilan siswa memiliki hubungan yang tidak begitu besar.
\end{abstract}

Kata Kunci : Media komunikasi massa, media pembelajaran, keterampilan siswa

FA Suherman, R Rahmawati, Sukarelawati. 2015. Motif Media Pembelajaran Buku Teks Biologi dan Hubungannya Dengan Keterampilan Siswa. Jurnal Komunikatio 1(2): 135-143. 


\section{PENDAHULUAN}

Ditinjau dari prosesnya, pendidikan adalah komunikasi dalam arti kata bahwa dalam proses tersebut terlibat dua komponen yang terdiri atas manusia, yakni pengajar sebagai komunikator dan pelajar sebagai komunikan (Onong Effendy,2003). Hal tersebut senada dengan yang dikatakan oleh Susilana\&Riyana (2009) proses pembelajaran merupakan proses komunikasi, artinya proses penyampaian pesan dari seseorang (sumber pesan) kepada seseorang atau sekelompok orang (penerima pesan).

Dilihat dari jumlah komunikannya, pendidikan termasuk pada komunikasi massa dan menggunakan salah satu media massa berupa buku teks. Hasil observasi penulis menunjukan bahwa jika dibandingkan dengan mata pelajaran lainnya, mata pelajaran Biologi memiliki tingkat kesulitan tersendiri, berbeda dengan mata pelajaran eksak seperti Fisika, Kimia, dan Matematika yang cenderung pada hafalan rumus. Buku teks sendiri bertujuan untuk membentuk siswa yang lebih terampil dan keterampilan siswa dapat dilihat dari kreativitasnya dalam banyak gagasan, keluesan dalam memecahkan masalah, mencetuskan gagasan asli, menguraikan sesuatu dengan rinci dan menghasilkan karyab aru. Dari gejala tersebut, menarik untuk diteliti dengan judul, "Motif Media Pembelajaran Buku Teks Biologi dan Hubungannya dengan Keterampilan Siswa."

Berdasarkan latar belakang yang telah diuraikan diatas, maka rumusan penelitian ini adalah sebagai berikut : (1) Bagaimana motif media pembelajaran buku teks Biologi bagi siswa SMA Taruna Andigha dan SMA Amaliah di Bogor? (2) Bagaimana keterampilan dalam belajar siswa di SMA Taruna Andigha dan SMA Amaliah Bogor? (3) Bagaimana hubungan antara motif media pembelajaran buku teks Biologi dengan keterampilan belajar siswa di SMATaruna Andigha dan SMA Amaliah Bogor?

Tujuan penelitian ini bertujuan untuk : (1) Mengtahui motif media pembelajaran buku teks Biologi bagi siswa SMA Taruna Andigha dan SMA Amaliah di Bogor, (2) Mengtahui keterampilan dalam belajar siswa di SMA Taruna Andigha dan SMA Amaliah Bogor, (3) Mengtahui hubungan antara motif media pembelajaran buku teks Biologi dengan keterampilan belajar siswa di SMATaruna Andigha dan SMA Amaliah Bogor. Adapun manfaat peneliian ini adalah: (1) Bagi pengembangan ilmu, untuk memberikan ko kontribusi terhadap kajian ilmu komunikasi, khususnya dibidang motif penggunaan media komunikasi massa dan sebagai masukan untuk pengajar dan langkah kedepannya dalam mempertimbangkan pemilihan media pembelajaran. (2) Bagi SMA Taruna Andigha dan SMA Amaliah, Sebagai masukan bagi sekolah terutama mengenai efektifitas media pembelajaran sebagai media pendukung pada proses belajar mengajar dan memberi wawasan kepada siswa bagaimana aktif berkomunikasi dengan guru melalui media. (3) Bagi Mahasiswa, dapat menyelesaikan tugas akhir dan mendapat pengalaman dalam meneliti sebuah kasus dengan metode yang sitematis, mengetahui lebih dalam wawasan dan ilmu tentang komunikasi, khususnya tentang motif dari penggunaan media komunikasi massa.

\section{KERANGKA PEMIKIRAN}

Komunikasi masa adalah dimana komunikator menyandikan pesan dan mengirimkannya kepada komunikan baik secara langsung maupun tidak langsung yang kemudian menguraikan sandi dan menghasilkan timbal balik. Komunikasi massa adalah proses dimana seseorang, sekelompok orang ataupun sebuah organisasi besar membuat sebuah pesan dan menyebarluarkannya dengan menggunakan sebuah media dan ditujukan untuk khalayak ramai, anonim dan heterogen. Didalam komunikasi masa, sumber pembuat pesan adalah seseorang yang profesional atau sebuah organisasi yang terlembagakan dengan biaya yang sangat besar. Pesan yang disampaikan dalam komunikasi massa tersebar dengan cepat dan bersifat umum dan melibatkan penerima pesan yang besar, heterogen dan anonim. Timbal balik yang didapatkan dari komunikasi masa tidak terjadi secara langsung dan tertunda. Komunikasi massa meliputi delapan industri tradisional seperti buku, koran, majalah, rekaman, radio, film, televisi, dan internet. (Stephen W Littlejohn \& Karen A Foss, 2009).

Karakteristik media pembelajaran (Buku teks biologi) sebagai media massa

1. Komunikasi berlangsung satu arah, komunikator pertama (departemen pendidikan) hanya menyampaikan 
informasi kepada kounikan (siswa) dan tidak mendapatkan feedback secara langsung.

2. Komunikator terlembagakan, buku teks dibuat oleh departemen pendidikan

3. Informasi atau pesan yang disampaikan bersifat umum, walaupun buku teks ditujukan secara khusus untuk siswa pada tingkat kelas tertentu namun pada isi pesan dapat dibaca oleh siapapun.

4. Media komunikasi menimbulkan keserempakan, buku teks disusun dengan satu kurikulum, sehingga menimbulkan keserempakan antara seluruh siswa.

5. Komunikan pada komunikasi massa bersifat heterogen, komunikan (siswa) disetiap daerah memiliki latar belakang yang berbeda-beda.

Tujuan atau motif dari buku teks biologi sendiri menurut penerbit buku teks biologi Grafindo Media Pratama yang ditulis oleh Oman Karmana (2008) adalah dengan adanya buku teks biologi siswa dapat memahami materi dan kedepannya dapat menyelesaikan masalah yang berkaitan dengan alam sekitar, selain itu siswa juga akan dapat lebih mengenali diri sendiri dan mengenal lingkungan dengan lebih baik. Dengan buku teks siswa diharapkan menjadi lebih menyadari akan kebesaran Tuhan Yang Maha Esa yang telah menciptakan kehidupan, hewan, tumbuhan, hingga mahkluk berselsatu yang tidak pernah terbayangkan sebelumnya. Diharapkan juga kedepannya siswa menjadi individu yang memiliki sikap jujur, objektif, ulet, kritis dan dapat bekerja sama dengan orang lain. Buku teks biologi yang disusun secara menarik dan sistematis diharapkan akan mampu memotivasi siswa untuk membuka diri dan siap menerima segala informasi yang berkaitan dengan pembelajaran biologi.

a. Menyampaikan materi pelajaran dapat diseragamkan

b. Proses pembelajaran menjadi lebih jelas dan menarik c. Proses pembelajaran menjadi lebih interaktif

d. Efisiensi dalam waktu dan tenaga

e. Meningkatkan kualitas hasil belajar siswa

f. Media memungkinkan proses belajar dapat dilakukan dimana saja dan kapan sana

g. Media dapat menumbuhkan sikap positif siswa terhadap materi dan proses belajar

h. Mengubah peran guru kearah yang lebih positif dan produktif (Kemp dan Dayton,1895 dalam Susilana\&Riyana, 2009)

Kreativitas merupakan saat dimana munculnya hasil dari ide baru dan ide lain yang relevan seperti, respon, proses atau produk (Litlejohn \& A.Foss, 2009).

Kreativitas yang melibatkan proses berpikir secara divergen, menemukan bahwa ada lima sifat yang menjadi ciri kemampuan berpikir kreatif, yaitu:

a. Kelancaran (Fluency), adalah kemampuan untuk menghasilkan banyak gagasan.

b. Keluwesan (Flexibility), adalah kemampuan untuk mengemukakan bermacam-macam pemecahan.

c. Keaslian (Originality), adalah kemampuan untuk mencetuskan gagasan dengan caracara yang asli.

d. d.Penguraian (Elaboration), adalah kemampuan untuk menguraikan sesuatu yang terinci.

e. Perumusan kembali (Redefinition), adalah kemampuan untuk merumuskan kembali suatu gagasan.(Guilford dalam Dedi Supriadi 1996)

Rhodes dalam Utami Munandar (1987:1) menyebutkan 4ciri kreativitas sebagai Four P's Creativity atau 4P, yaitu: a. Person, merupakan keunikan individu dalam pikiran dan ungkapanya. b. Process, yaitu kelancaran, fleksibilitas, dan orisinil dalam berpikir. c. Press, merupakan situasi kehidupan dan lingkungan sosial yang member dorongan untuk menampilkan tindakan kreatif. d. Product, diartikan sebagai kemampuan dalam menghasilkan karya yang baru dan orisinil serta bermakna bagi individu dan lingkunganya 


\section{Gambar 1. Kerangka Pemikiran Penelitian}

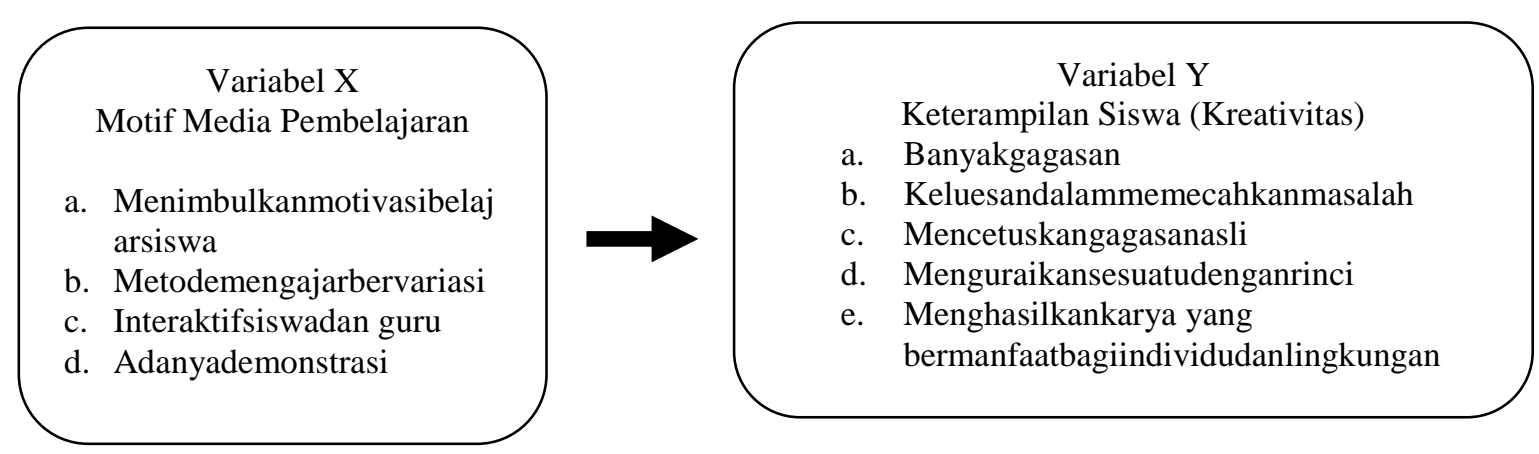

Adapun hipotesis dalam penelitian ini adalah sebagai berikut :

Ha : Motif media pembelajaran memiliki korelasi yang nyata dengan keterampilan siswa (kreativitas).

Ho : Motif media pembelajaran tidakmemiliki korelasi yang nyata dengan keterampilan siswa pada (kreativitas).

\section{METODE PENELITIAN}

Metode penelitian ini adalah metode penelitian kuantitatif asosiatif dengan perolehan data ordinal dan kemudian diukur dengan skala likert dengan pemberian skor menggunakan rumus weight mean score, lalu dihitung dengan range Spearman menggunakan SPSS. Penelitian akan dilakukan pada siswa kelas XI IPA SMA Taruna Andigha dan SMA Amaliah Bogor.

Populasi yang didapatkan di SMA Taruna Andigha adalah 60 orang dan 42 orang di SMA Amaliah Bogor, kemudian dengan menggunakan rumus Yamane dengan tingkat presisi kesalahan 5\% didapatkan sampel sebanyak 82 orang dan untuk pembagian jumlah sampel dikedua sekolah dilakukan pembagian menggunakan rumus turunan yamane sehingga didapatkan sampel untuk SMA Taruna Andigha sebanyak 42 orang dengan jumlah sampe laki-laki sebanyak 21 orang dan sampel perempuan sebanyak 28 orang. Untuk SMA AMALIAH didapatkan sampel sebanyak 23 orang, dengan jumlah sampel laki-laki 13 orang dan sampel perempuan 15 orang.

\section{HASIL DAN ANALISIS DATA}

Hubungan Motif Media pembelajaran dengan keterampilan siswa

Tabel 1. Rekapitulasi Operasional Variabel $\mathbf{X}$

\begin{tabular}{|c|c|c|}
\hline No Indikator & $\begin{array}{r}\text { Rata- } \\
\text { rata } \\
\text { skor }\end{array}$ & $\begin{array}{c}\text { Kriteria } \\
\text { penafsiran }\end{array}$ \\
\hline
\end{tabular}

1 Dengan buku teks siswa dapat menemukan banyak gagasan dalam menjawab permasalahan yang sesuai objek materi yang dibahas.

2. Buku teks membuat siswa menemukan ide baru untuk 3,6 mengembangkan materi.

3. Membantu siswa lancar dalam berpikir didalam diskusi. 
4. Bukut teks membantu siswa menyelaraskan pendapat dalam berdiskusi.

\section{Keluwesan memecahkan masalah}

5. Siswa dapat menemukan bermacam-macam pemecahan 3,3 Baik terhadap masalah.

6. Membantu siswa melihat kenyataan tentang suatu objek yang dibahas dalam materi.

\section{Mencetuskan gagasan asli}

7. Buku teks Biologi membantu siswa untuk menemukan suatu $3,8 \quad$ Baik ide baru.

\section{Menguraikan sesuatu dengan rinci}

8. Buku teks membantu siswa untuk menjelaskan sesuatu dengan rinci dan sesuai dengan materi.

Baik

3,9

9. Buku teks membantu siswa untuk menjawab permasalahan ssesuatu objek berdasarkan sebab akibat.

Menghasilkan karya yang bermanfaat bagi individu dan lingkungan

10. Buku teks membantu siswa untuk menghasilkan suatu karya baru, baik untuk diri sendiri ataupun untuk lingkungan sekitar.

11. Siswa tidak mudah terpengaruh akan pendapat orang lain atau lebih percaya diri dengan pendapatnya. Jumlah Rata-rata Skor Rata-rata skor keseluruhan

14,9 Kurang baik 2,9

Berdasarkan hasil rekapitulasi operasionalisasi variabel Y pada tabel 25 , terlihat bahwa nilai rata-rata indikator pada variabel $\mathrm{Y}$ yakni kreativitas siswa diperoleh angka penafsiran 2,9 (antara 2,4 - 3,2) yang dapat diartikan berada dalam kategori kurangbaik.

Tabel 2. Rekapitulasi Operasional Variabel Y

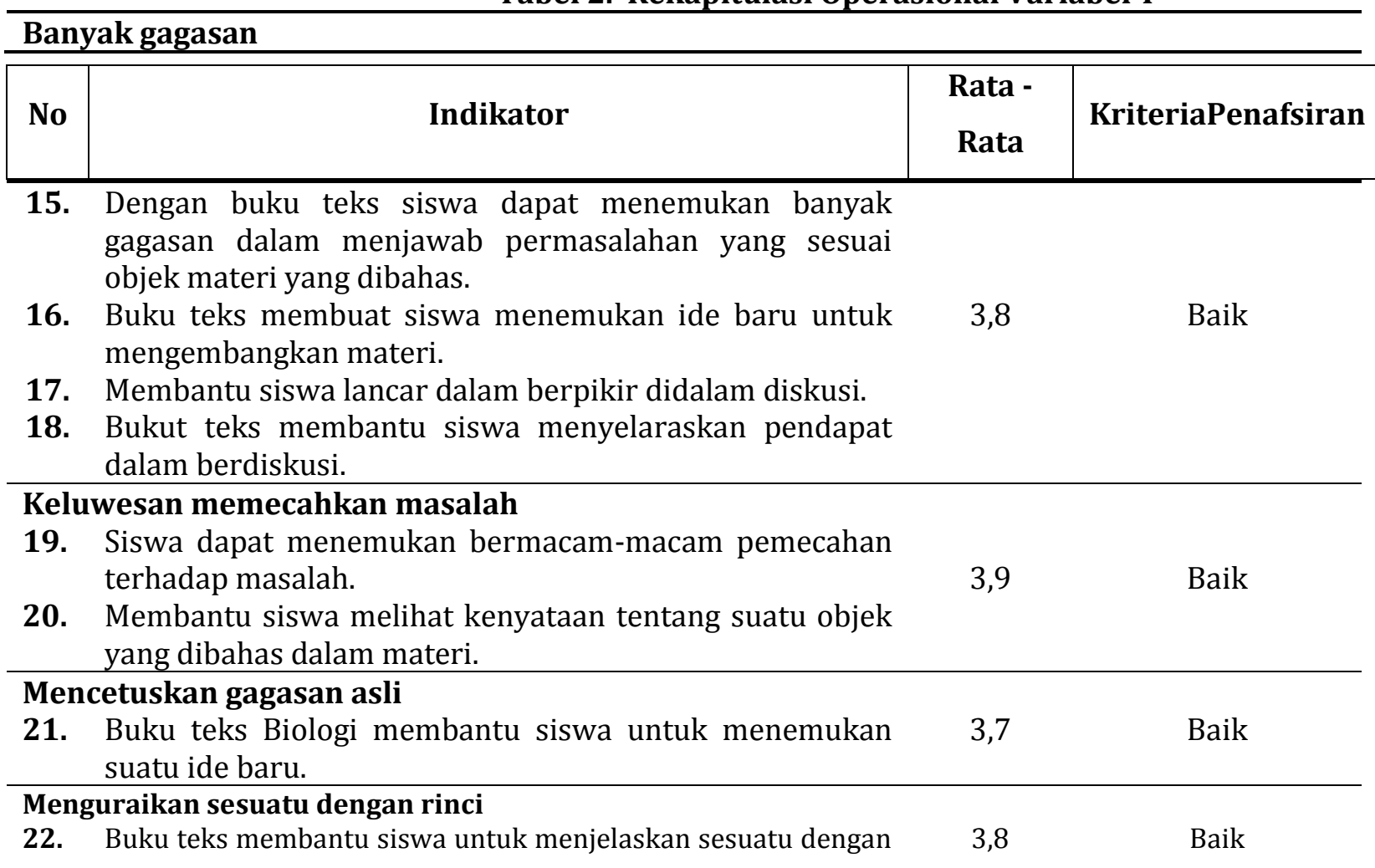


rinci dan sesuai dengan materi.

23. Buku teks membantu siswa untuk menjawab permasalahan ssesuatu objek berdasarkan sebab akibat.

Menghasilkan karya yang bermanfaat bagi individu dan lingkungan

24. Buku teks membantu siswa untuk menghasilkan suatu Baik karya baru, baik untuk diri sendiri ataupun untuk lingkungan sekitar.

25. Siswa tidak mudah terpengaruh akan pendapat orang lain atau lebih percaya diri dengan pendapatnya. Jumlah rata-rata skor

Baik

Berdasarkan hasil rekapitulasi operasionalisasi variabel $Y$ pada tabel 57, terlihat bahwa nilai rata-rata indikator pada variabel $\mathrm{Y}$ yakni kreativitas siswa diperoleh angka penafsiran 3,8 (antara 3,3 - 4,1) yang dapat diartikan berada dalam kategori baik.
Untuk mengetahui korelasi antara Motif media pembelajaran buku teks biologi dengan keterampilan siswa, digunakan rumus Range Spearman dengan menggunakan bantuan aplikasi komputer SPSS. Adapun hasil dari analisis sebagai berikut :

Tabel 3. Hubungan korelasi motif media pembelajaran dengan keterampilan siswa

\begin{tabular}{|l|r|r|l|r|r|}
\hline & $\begin{array}{r}\text { Banyak } \\
\text { gagasan }\end{array}$ & $\begin{array}{r}\text { Keluwesan } \\
\text { memecahka } \\
\text { n masalah }\end{array}$ & $\begin{array}{l}\text { Mencetuska } \\
\text { asli }\end{array}$ & $\begin{array}{r}\text { Menguraika } \\
\text { g sesuatu } \\
\text { dengan } \\
\text { rinci }\end{array}$ & $\begin{array}{r}\text { Menghasilkan karya baru } \\
\text { yang bermanfaat bagi } \\
\text { individu dan lingkungan }\end{array}$ \\
\hline $\begin{array}{l}\text { Menimbulkan } \\
\text { Motivasi }\end{array}$ &, 500 & $-1,000$ &. & $-1,000$ & $-1,000$ \\
\hline $\begin{array}{l}\text { Metode mengajar } \\
\text { bevariasi }\end{array}$ &,- 632 &. &. &. & 1,000 \\
\hline $\begin{array}{l}\text { Interaktif siswa } \\
\text { danguru }\end{array}$ &, 400 & 1,000 &. & 1,000 & \\
\hline $\begin{array}{l}\text { Adanya } \\
\text { Demonstrasi }\end{array}$ & 1,000 & 1,000 &. & & 1,000 \\
\hline
\end{tabular}

1. Media pembelajaran menimbulkan motivasi memberikan pengaruh yang tidak begitu banyak dan tidak nyata. Hal ini dikarenakan buku teks yang siswa baca atau gunakan baca hanya membuat pengetahuan siswa terbatas pada apa yang ditulis dalam buku sehingga gagasan siswa pun terbatas hanya pada apa yang dia baca saja.
2. Media pembelajaran menimbulkan motivasi berhubungan negatif dan tidak nyata dengan keluwesan memecahkan masalah, menguraikan sesuatu dengan rinci dan menghasilkan karya yang baru. Hal ini dikarenakan walaupun buku teks membantu siswa memecahkan masalah, dan menguraikan sesuatu dengan rinci siswa 
tetap lebih akan memahami materi jika media yang digunakan adalah dengan melakukan praktek di lab atau observasi langsung ke lapangan.

3. Metode mengajar bervariasi memiliki hubungan namun kearah negatif dengan siswa memiliki banyak gagasan dan tidak memiliki hubungan nyata. Hal ini dikarenakan bervariasi yang dimaksudkan disini adalah siswa mendengarkan dan membaca dan gagasan-gagasan siswa cenderung lebih dipengaruhi oleh intensitas siswa dalam belajar dan berdiskusi baik dengan teman-temannya ataupun dengan guru.

4. Interaktif siswa dan guru memiliki hubungan yang baik namun tidak nyata dengan siswa banyak gagasan, keluwesan memecahkan masalah, menguraikan sesuatu dengan rinci, dan menghasilkan karya bagi lingkungan atau individu. Hal ini dikarekanakn saat terjadi hubungan interaktif antara siswa dan guru, siswa dapat menyampaikan berbagai macam gagasan yang dimilikinya dan dari gagasangagasan tersebut dimungkinkan untuk terciptanya karya baru yang bermanfaat. Saat terjadi interaktif pun siswa menjadi lebih terbuka pikirannya mengenai caracara memecahkan masalah sehingga pada akhirnya siswa dapat menguraikan sesuatu dengan rinci.

5. Adanya demonstrasi memiliki hubungan yang baik namun tidak nyata dengan siswa

\section{UjiHipotesis}

Uji hipotesis untuk mengetahui hubungan antara motif media pembelajaran dengan banyak gagasan, keluwesan memecahkan masalah, menguraikan sesuatu dengan rinci, dan menghasilkan karya bagi lingkungan atau individu. Hal ini dikarenakan dengan penggunaan buku teks, guru dapat memberikan demonstrasi atau sebalikanya murid pun dapat melakukan demonstrasi, hal tersebut lah yang membuat siswa menjadi banyak gagasan, karena saat mengamati demonstrasi atau saat diminta unutk malakukan demonstrasi, siswa akan melakukan pengamatan lebih mendalam sehingga membuat siswa lebih luwes dalam memecahkan masalah setelahnya dan bahkan dapat menghasilkan sebuah karya baru baik bagi individu ataupun lingkungan. Dengan melakukan pengamatan lebih mendalam pada objek nyata yang didemonstrasikan pun membuat siswa lebih paham dan mengerti sehingga membuat siswa dapat menjelaskan sesuatu secara rinci.

6. Seluruh indikator media pembelajaran tidak ada hubungannya dengan mencetuskan gagasan asli. Hal ini dikarenakan, media pembelajaran hanya membantu siswa dalam beberapa hal tertentu saja tapi utuk menciptakan gagasan asli yang murni berasal dari pikirannya sendiri siswa membutuhkan media lain dan lebih banyak berkomunikasi atau diskusi dengan pengajar, juga dengan melakukan pengamatan pada lingkungan sekitar.

keterampilan siswasecara menyeluruh berdasarkan uji korelasi Range spearman, dapat dilihat dari tabel di bawah ini :

Tabel 4 Hasil SPSS Motif media pembelajaran dan hubungannya dengan keterampilan siwa di SMA Taruna Andigha dan SMA Amaliah

\begin{tabular}{|lll|r|r|}
\hline \multicolumn{2}{|c|}{} & \multicolumn{1}{c|}{ X } & \multicolumn{1}{c|}{ Y } \\
\hline Spearman's rho & Motif media pembelajaran & $\begin{array}{l}\text { Correlation } \\
\text { Coefficient }\end{array}$ & 1,000 &, 272 \\
\cline { 2 - 5 } & Keterampilan siswa & $\begin{array}{l}\text { Correlation } \\
\text { Coefficient }\end{array}$ &, 272 & 1,000 \\
\hline
\end{tabular}


Berdasarkan tabel 30 diatas analisis Range Spearman antara motif media pembelajaran dengan keterampilan siswadi SMA Taruna Andigha dan SMA Amaliah didapat koefisien sebesar 0,272. Jika dilihat pada pedoman interpretasi koefisien korelasi, dimana nilai koefisien korelasi (r) didapat sebesar 0,272 yang terletak diantara wilayah $0,20-0,39$ yang berada di level rendah, maka dapat disimpulkan bahwa korelasi diantara kedua variabel $X$ (motif media pembelAjaran) dan variabel $Y$ (keterampilan siswa) memiliki hubungan yang rendah dan menunjukan hubungan tidak siginifikan.

\section{KESIMPULAN DAN SARAN}

\section{Kesimpulan}

Motif media pembelajaran buku teks biologi SMA Taruna Andigha dan SMA Amaliah di Bogor dapat disimpulkan salah satunya untuk menutupi adanya kesalahan interpretasi pesan antara guru dan siswa, sebab ada kalanya terjadi hambatan dalam berkomunikasi seperti siswa tidak mendengar dengan jelas atau tertinggal materi dikarenakan tidak dapat hadir dikelas atau terlambat masuk kelas dikarenakan satu dan lain hal. Dalam hal ini lembaga pendidikan sebagai komunikator yang

\section{DAFTAR PUSTAKA}

Ardianto, Elvinaro. 2010. Metode Penelitian Untuk Public Relations Kuantitatif dan Kualitatatif. Bandung (ID): Remaja Rosdakarya

Efendy, Onong. 2003. Ilmu Komunikasi Teori dan Praktek. Bandung (ID): Remaja Rodakarya

Karmana, Oman. 2008. BIOLOGI. Bandung (ID) : Grafindo Media Pratama. menyusun media pembelajaran sebagai rumpun media massa tidak cukup berhasil memenuhi tujuannya untuk membentuk keterampilan siswa.

Timbal balik yang komunikator inginkan (lembaga pendidikan) dari komunikan (siswa) adalah membentuk siswa yang terampil, keterampilan siswa dalam penelitian ini dipengaruhi oleh adanya alat alat penunjang seperti lab serta alat dan bahan untuk melakukan praktek sebagai kesempatan siswa untuk mengamati dan mempraktekan secara langsung mengenai objek suatu materi.

Hasil penelitian menunjukan bahwa motif media pembelajaran dan keterampilan siswa tidak sepenuhnya saling berhubungan.

\section{Saran}

Buku teks (media pembelajaran) disarankan tetap digunakan sebagai media pembelajaran karena hasil penelitian menunjukan bahwa ada hubungan antara motif media pembelajaran dengan keterampilan siswa, walaupun hasil tidak menunjukan pengaruh yang signifikan. Sehingga selain siswa perlu lebih cermat memahami isi materi tetapi juga isi materi lebih banyak diperoleh di laboratariom agar membantu siswa lebih terampil. diharapkan ada alat bantu lain yang digunakan oleh lembaga pendidikan agar dapat lebih membantu siswa melakukan praktek dan membentuk siswa menjadi lebih terampil.

Litlejohn Stephen W. dan Foss Karen A. 2009. Encyclopedia of communication theory. USA (USA) : SAGE Publication, Inc.

Mayer, Richard E. 2001. Multimedia Learning. Cambridge (AU): Cambridge University Press.

Morisan. 2010. Komunikasi Massa. Bogor (ID): Ghalia Indonesia

Mulyana, Dedi. 2008. Ilmu Komunikasi Suatu Pengantar. Bandung (ID): Remaja Rodakarya 
Rhodes, 1990. The Phi Delta Kappan (An Analysis of Creativity). USA : Sagepub, Inc.

Sugiyono. 2013. Metode Penelitian Administrasi. Bandung (ID): CV. Alfabeta

Susilana, Rudi \& Riyana, Cepi. 2004. Media Pembelajaran (Hakikat, Pengembangan, Pemanfaatan, Penilaian). Bandung (ID): CV. Wacana Prima.

Gangguly, S. 2004. Communication Media, Systems and Strategy. USA (USA) : Sagepub, Inc.

King, Patricia M \& Van Hecke, Jones R. 2000, Using Skill Theory to Recognize How Students Build and Rebuild Understanding, Making Conections, P-7.

Liz Banse.2012. Seeing is Believeng. Resource media.

www.bos.kemdibud.go.id/home/about diakses pada 15 maret 2015 pada puku 9:46

www.wikipedia.org/wiki/skill diakses pada 9 maret 2015 pada pukul 9.20 